Article

\title{
Developing Process Designs for Biorefineries-Definitions, Categories, and Unit Operations
}

\author{
Tanmay Chaturvedi ${ }^{1, *}$, Ana I. Torres ${ }^{2}$, George Stephanopoulos ${ }^{3}$, Mette Hedegaard Thomsen ${ }^{1}$ \\ and Jens Ejbye Schmidt ${ }^{4}$ \\ 1 Department of Energy Technology, Aalborg University, Niels Bohrvej 8, DK-6700 Esbjerg, Denmark; \\ mht@et.aau.dk \\ 2 Facultad de Ingeniería, Instituto de Ingeniería Química, Universidad de la República, Julio Herrera y Reissig \\ 565, Montevideo 11300, Uruguay; aitorres@fing.edu.uy \\ 3 Department of Chemical Engineering, Massachusetts Institute of Technology, 77 Massachusetts Avenue, \\ Cambridge, MA 02139, USA; geosteph@mit.edu \\ 4 Institute of Chemical Engineering, Biotechnology and Environmental Technology, University of Southern \\ Denmark, Campusvej 55, 5230 Odense M, Denmark; jesc@kbm.sdu.dk \\ * Correspondence: tac@et.aau.dk; Tel.: +45-71441674
}

Received: 20 February 2020; Accepted: 20 March 2020; Published: 21 March 2020

check for updates

\begin{abstract}
In this review, we focus on the literature that described the various unit operations in a process design flowsheet of biorefineries. We begin by establishing the accepted definitions of a biorefinery, go on to describe how to categorize biorefineries, and finally review the literature on biorefinery process designs by listing the unit operation in each process design. Distinguishing biorefineries based on feedstock, the types of processing units, and the products emanating from the biorefinery are discussed.
\end{abstract}

Keywords: biomass; bio-products; process design; biorefinery; lignocellulose; proteins; waste; microalgae

\section{Introduction}

The process design of biorefineries has been built upon the backbone of traditional chemical-based process synthesis, analysis, and design, an area that has been well-studied for nearly over a century [1]. Chemical-based process synthesis has evolved over time to identify the processing routes required to produce desired products, the identification of involved chemical reactions, the selection and design of unit operations involved in the processing route, the calculation of utilities, waste, emissions, etc. [2]. However, biomass-based processing have a long way go in this regard. Although some biomass processing routes, such as corn to ethanol andwaste to biogas, have been well-studied and established, most other biomass processing routes remain commercially non-competitive and open to continuing research and development [3-7].

The primary reason to develop process design models of biorefineries is to construct functional and conceptual process flowsheets while utilizing data from biomass processing experiments available in the literature. Once benchmark cases are developed, future research and its anticipated results can be used for scaling up the pathway, as a blue-print to design demonstration biorefineries, etc. [8]. Even incremental technological developments and new research in one specific unit process can have positive implications on complementary technologies in the system. Moreover, minor changes in one unit operation can influence the economics of the overall design, with, for example, probable reduction 
in total costs and/or increased products yields. Hence, complete process design and economics often provide the insights required to assess the overall feasibility of a biorefinery.

To find optimal products from biomass, the study of process design tools must be combined with open-ended solutions involving competing approaches. These approaches are broadly classified into three main methods: firstly, those that employ heuristics or are knowledge based; secondly, methods that employ mathematical or optimization techniques; and, lastly, hybrid methods that combine different approaches into one method [9]. Process design can provide advanced process synthesis and optimization platforms to construct biorefinery systems, which are economically viable, energy efficient, and have minimum environmental footprint. This involves the selection and matchmaking of various unit operations to convert given set of inputs to emanate a desired set of products. The design objectives can be to develop a process flow with, for example, higher yields, minimum cost (or high profitability), high-energy efficiency (minimizing resource utilization) and/or minimum environmental impact. The prominent approaches to process optimization require the use of heuristics, development of physical insights, and optimization of superstructure alternatives [10-13].

In this review, we limit our focus on process design, and decide not to cover process optimization. Biomass processing and utilization has been studied in detail from process optimization perspectives [2,14-16]. However, a literature review where various unit operations for similar types of biomass processing routes is listed along with the products, is still missing. A vast majority of the existing process models are conceived due to the availability of a feedstock and the wealth of knowledge in processing the feedstock $[12,17,18]$. Rarely have biorefineries been modelled where the product is the priority and the feedstock have been selected based on targeted products. However, with an increasing need to find alternative pathways for the production of sustainable liquid fuels, chemicals, fertilizers, and energy from biomass, biorefinery analysis often relies on process design methodology to find novel solutions $[19,20]$. In this methodology, once the feedstock and processing routes have been narrowed down, the next step is an appropriate choice of a process design software.

Process design models are often developed on dedicated process simulation software, which permits mass, energy and emission balances that can be extrapolated to make economic decisions. These process design tools/software are quite powerful in their calculations. Their accuracy depends on the level of detail provided by the user and the familiarity of the user with the software itself. Biorefinery process models have been developed on Aspen Plus, SuperPro Designer, Matlab and Microsoft Excel [21-27]. Table 1 below summarizes the conditions under which different commercial simulators are best suited for use.

Table 1. Commercial software packages for process design flowsheet simulation.

\begin{tabular}{cccccc}
\hline & EXCEL & EXTEND & SuperPRO & ASPEN & gPROMS \\
\hline Mass balance & $\square$ & - & $\square$ & $\square$ & - \\
\hline Mass and heat balance & $\square$ & - & $\square$ & $\square$ & - \\
\hline Batch-Discrete & - & $\square$ & $\square$ & $\square$ & - \\
\hline Continuous & - & - & $\square$ & $\square$ & $\square$ \\
\hline Dynamic & & - & - & $\square$ & $\square$ \\
\hline
\end{tabular}

In this review, we focus on the literature that has detailed process design flowsheets of biorefineries, irrespective of the software used. However, we begin first by establishing the accepted definitions of a biorefinery, then go on to describe how to categorize biorefineries, and finally review the literature on biorefinery process designs by listing the type of biorefinery. Finally, we discuss the categorization of biorefineries based on feedstock, type of processing units in designed flowsheets, and biomass-based products emanating from the biorefinery. 


\section{Context of a Biorefinery}

Several definitions of biorefineries exist, however one of the most accommodating explanations of biorefining was given by the International Energy Agency as "the sustainable processing of biomass into a spectrum of marketable products and energy" [28]. The biorefinery concept embraces a wide range of processing and separation technologies able to modify biomass resources (wood, corn, beetroot, sugarcane, switch grass, etc.) into fractions (carbohydrates C5 or C6, lipids, proteins, triglycerides, etc.) which can further be converted to value-added products, biofuels, biomaterials, fertilizers, and chemicals. The biorefinery concept is analogous to contemporary petroleum refineries, which produce a wide variety of fuels and products from crude oil; however, in biorefineries, biomass replaces crude oil as the raw material. It might be argued that crude oil is, in fact, derived from biomass, by several hundreds of years of slow decay; however, in this context crude oil is not considered as biomass.

Bioenergy will be an important contributor in meeting future energy demands from clean and sustainable energy sources. This means that constant innovation in biomass processing technologies is needed to develop a sustainable bio-based society which is capable of looking beyond bioenergy and biofuels, and tapping into the opportunity to produce a myriad of products stemming from biorefineries [29]. The reliable and efficient production of biofuels can also provide stability to the volatile global oil prices [29]. In fact, with the steadfast growth in the transportation sector, the demand for renewable fuels is only going to increase. While biofuels provide a cleaner alternative to existing fuel options, the electric vehicles have a strong market penetration and compete with both the biofuel and fossil fuel production industry [30]. Consequently, the challenge for current and future biorefinery development will be the efficient and cost- effective production of biofuels, while ensuring that they search for alternative products. The coproduction of biomaterials and biochemicals will provide a new dimension to the biorefinery business model, by reducing the dependence on liquid biofuels for revenues [31]. Currently, the prominent biomass-based commodities manufactured by converting biomass include starch, oil, cellulose, biogas, and biofuels $[19,20]$. In addition, bio-chemicals such as lactic acid, glycerin, succinic acid, amino acids, levulinic acid, sorbitol, and xylitol, along with commercially available bio-based products such as lubricants, solvents, polymers, paper, paint, plastics, adhesives, dyes, detergents, cleaning compounds, inks, and adhesives, are also by-products of a biorefinery $[19,20,32]$. It is estimated that the need to find alternative sources to derive these products from will continue to provide a market segment that is willing to adapt to new feedstock in the supply chain if the economic benefits can be proven $[33,34]$. Most of the existing biofuels and biochemicals that are currently being produced in single-pathway productions are not within the confines of a biorefinery setup (since they do not utilize more than one feedstock and do not produce multiple products). However, this does not mean that the importance of large-scale single feedstock to single-product biorefineries can be undermined in studying the collaborative style of designing processes for a biorefinery. The industrial setups of combining synergetic biorefineries, such as the one in Kalundburg, Denmark, provide valuable expertise in this context. In Kalundburg, several bio-industries can combine their material flows in order to reach a closed-loop utilization of all streams in a system: the residue and waste heat from one bio-industry is utilized by another, eventually giving rise to an integrated bio-industrial system [35]. This is an example wherein different companies have worked together to maximize the utilization of by-product streams, thereby reducing unused streams and converting them into profitable products. The interdependence of systems is an embodiment of the biorefinery concept, where the integration of conversion processes and equipment can give rise to a circular system to produce biofuels, biochemicals, and a wide range of other bio-based products from various types of biomass, while still being able to produce bio-energy as a 'side stream'.

In the past, the selection of feedstock for biorefining was primarily done on the basis of sustainable year-round supplies of biomass, thus allowing for the biorefinery to be classified based on type of feed [36-38]. While optimizing the direct production costs of bio-based products is an important area to focus, $40-60 \%$ of the total operating costs of a biorefinery are spent on purchasing or 
growing the feedstock [39]. Thus, feedstock still remains the primary driver for a biorefinery design; on a per-gallon basis of ethanol production the feedstock price equates to $30-32 \%$ of the total production cost [25]. Amongst the different types of biomass, lignocellulosic biomass has been extensively studied for utilization in a biorefinery. Galbe et al. [40] had made comparisons between the types of biorefineries based on lignocellulosic feedstock and starch containing biomasses. Due to familiarity with the crop and its processing, coupled with land use, socio-economic and environmental issues, lignocelluloses are preferable to the starch-containing materials, thus drawing the first category of a biorefinery based on feed [40]. Increasing attention is also being given to biofuels produced from second-generation lignocellulosic biomass, as this biomass does not compete with food crops. Each biomass, whether lignocellulosic or starch based, can be processed in various ways, depending upon the required product. This led to researchers reviewing biorefineries based on the possible processing pathways deployed for targeted feedstock. Damartzis and Zabaniotou reviewed the thermochemical conversion to second-generation biofuels through an integrated process design [41]. Bulushev and Ross reviewed the conversion of biomass via pyrolysis and gasification [42]. Bridgwater and Double reviewed the production costs of liquid fuels from biomass via various routes using a techno-economic simulation [43]. These approaches were succeeded with the idea of an integrated process design capabale of coverting multiple feedstock into various bio-products, such as fuels, chemicals, and energy, thereby providing a flexible approach by varying the constrainsts of the system. $[12,29,44]$. Centi et al., expanded the techno-economic view to entail the social and political impact of second-generation biofuels [45]. Cherubini et al., expanded their scope to combine first and second generation biofuels in their discussion [46]. Kokossis and Yang highlighted that with increasingly more complex process designs, higher degrees of freedom in feedstock choices, processing technologies, and variety of products available, the role of systems engineering for optimizing and modelling biorefinery process designs is more pronounced now than it has been in recent years [47]. The possibility of utilizing a wide array of biomass through various processing techniques to produce a variety of products has led to a complex optimization problem. In searching for methodologies to solve this optimization problem, process design has become a central reliable approach towards looking at different processing routes for various types of biomass to produce the most profitable bio-based products. As a result, researchers have defined their interest in either technologies, products or a combination of both, and successfully reviewed the available literature in their selected area of focus. Some reviewers have further intensified their focus by selecting specific biomasses and studying them against various processing technologies, or vice-versa. In this paper, we begin by describing biorefineries based on feedstock, processes and products.

\section{Feedstock}

The term 'feedstock' refers to the raw materials used in a biorefinery. Biomass is a broad term that entails a wide variety of plants species, each of which vary in their physical structure and chemical composition. Regardless of the phenotype, biomass can been classified into four main components: lipids, carbohydrates (starch, cellulose, and hemicelluloses), lignin, and proteins. Biomass synthesized via the photosynthetic process converts atmospheric carbon dioxide and water into sugars. Plants use this sugar to synthesize complex materials to provide energy for themselves. Proteins in biomass is synthesized much the same way as in all eukaryotic organisms, where amino acids serve as the building blocks of proteins. Plants extract nitrates (a form of nitrogen) from roots and convert them into amino acids. Ribosomes cumulate amino acids to form an elongating peptide chain, which often combines with phosphate or other chemical groups to form proteins. One of the most important requirements of a biorefinery is the consistent, regular, and renewable supply of feedstock, making this the defining factor for several biorefinery designs.

Renewable carbon-based raw materials for biorefineries are provided from four different sectors [29]:

(a) Agriculture (dedicated crops and residues); 
(b) Forestry;

(c) Industries (process residues and leftovers);

(d) Households (municipal solid waste and wastewaters);

(e) Aquaculture (algae and seaweeds).

Further distinctions can be made within dedicated crops and residues from agricultural, forestry and industrial activities; however, these are beyond the purview of this paper. Biomass can be broken down into three building blocks categorized as: carbohydrates and lignin; triglycerides; mixed organic residues and proteins [29].

\subsection{Carbohydrates and Lignin}

Carbon, hydrogen, and oxygen are the most common biomass components found in plant feedstock and make up carbohydrates (such as starch, cellulose and hemicellulose). Six-carbon, or C6, single-molecule 'monosaccharide' sugars $\left(\mathrm{C}_{6} \mathrm{H}_{12} \mathrm{O}_{6}\right)$ include glucose, galactose and mannose, while the most common five-carbon sugars $\left(\mathrm{C}_{5} \mathrm{H}_{10} \mathrm{O}_{5}\right)$ are xylose and arabinose. Sugarcane and sugar beet are the two most important sugar crops, and together with corn (a starch crop), they supply almost all the feedstock food the ethanol that is produced today [48].

Lignin is the third polymeric organic component of lignocellulose. It is a complex chemical compound most commonly derived from wood, and an integral part of the secondary cell walls of plants [49]. It is usually located between the cellulose microfibrils, where it serves to resist compression forces (increases mechanical strength). Lignin is very complex in structure. When viewed in three dimensions, this polymer is composed of different phenolic units bound together by ether and carbon-carbon bonds. A closer look at the complexity of lignin chemical structure is presented in Figure 1. As a biopolymer, the handling of lignin is more difficult due to its lack of a defined primary structure. Its main purpose is to provide structural integrity by strengthening wood (xylem cells) in trees. The random and high degree of polymerization of lignin has made it an intensive field of study, and thereby more difficult to convert into smaller chains of similar compounds [50]. The three more commonly isolated monolignol monomers, methoxylated to various degrees are:

(1) P-coumaryl alcohol;

(2) Coniferyl alcohol;

(3) Sinapyl alcohol.

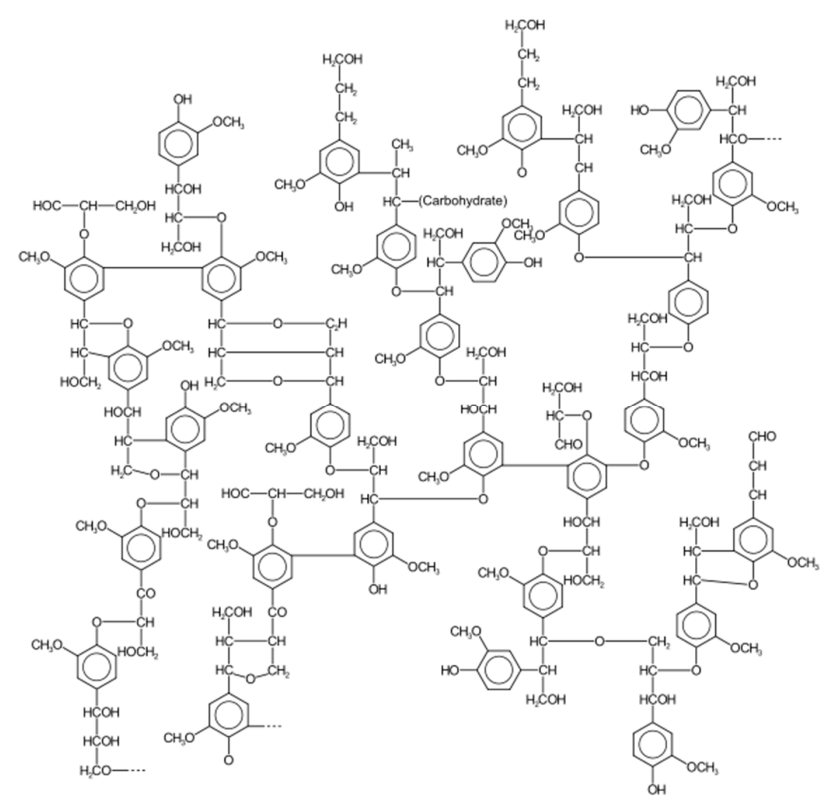

Figure 1. Lignin Structure [51]. 
Starch $\left(\mathrm{C}_{6} \mathrm{H}_{10} \mathrm{O}_{5}\right)_{n}$ is a very large polymer molecule, or 'polysaccharide', composed of thousands of glucose molecules. These molecules must be broken down into smaller chains called monosaccharides or disaccharides prior to being fermented. Corn and wheat are the most commonly used starch crops in a biorefinery $[3,52,53]$. Once sugars have been depolymerized (for starch crops) or extracted (from sugar crops) they can be easily fermented to ethanol, or used as a substrate for chemical reactions or enzymatic hydrolysis, presenting the opportunity to produce a wide variety of chemical products.

Lignocellulose is a complex raw material consisting of cellulose (35-45\% of total dry weight), hemicellulose, (20-40\%), and lignin (10-30\%) [54]. Lignocellulose biomasses have a compact and rigid structure of cellulose and a close association of cellulose and hemicellulose with lignin, leaving very few reactive sites available for enzyme attachment. This is the primary reason that it does not degrade/degrades very slowly under the influence of microorganisms. A typical lignocellulosic structre can be seen in Figure 2. Cellulose $\left(\mathrm{C}_{6} \mathrm{H}_{10} \mathrm{O}_{6}\right)_{\mathrm{n}}$ consists of long chains of $\mathrm{C} 6$ (sugar) glucose molecule [55]. Glucose is different from starch in their configuration of bonds across the oxygen molecule that joins two hexose units. In addition, starch can be easily hydrolyzed to monomeric sugars in the presence of enzymes or acids, while cellulose is much more resilient to hydrolysis. Hemicellulose $\left(\mathrm{C}_{5} \mathrm{H}_{8} \mathrm{O}_{5}\right)_{\mathrm{n}}$ is an amorphous $\mathrm{C} 5$ sugar, which is easier to break down with chemicals and/or heat than cellulose. Lignin $\left(\mathrm{C}_{9} \mathrm{H}_{10} \mathrm{O}_{2}\left(\mathrm{OCH}_{3}\right)_{n}\right)$, is a complex chemical compound, usually located between the cellulose microfibrils, where it serves to resist compression forces (which increases mechanical strength). Polysaccharides such as cellulose and hemicellulose can be hydrolyzed to sugars and subsequently fermented to alcohols. Lignin, however, cannot be fermented, and is thus predominantly used in energy generation or chemical extraction. While cellulose and hemicellulose are polysaccharides that can be hydrolyzed to sugars and then fermented to ethanol, lignin cannot be used in fermentation processes, but it may be useful for other purposes (chemical extraction or energy generation).

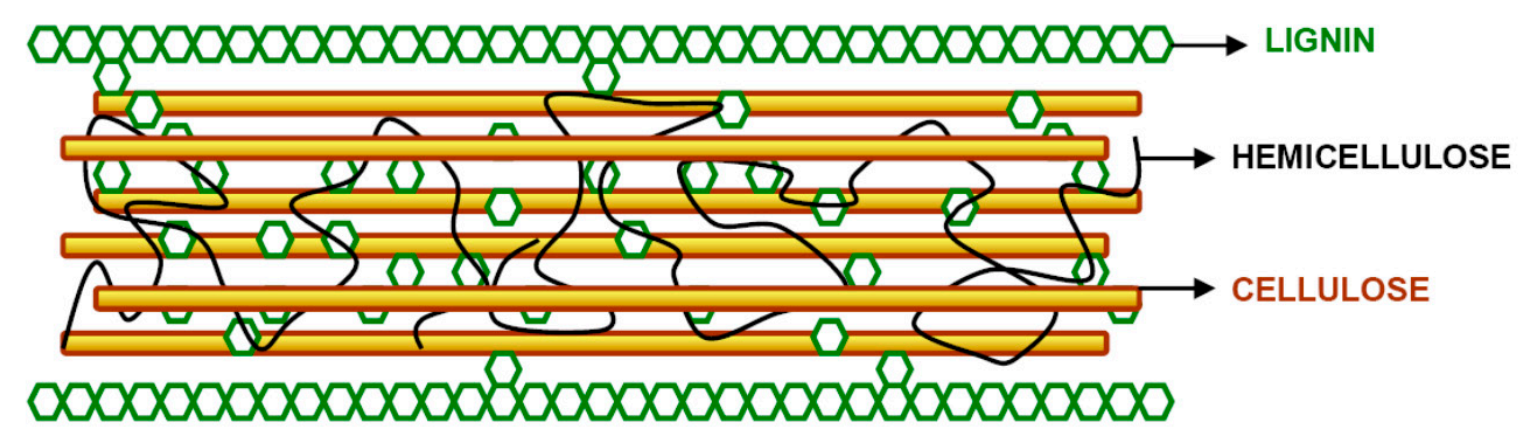

Figure 2. Typical lignocellulosic structure [56].

Lignocellulosic biomass is available either as crop or as agricultural residue. Lignocellulosic biomass can be produced via crop rotation or dedicated plantations of herbaceous plants. Large amounts of cellulosic biomass can be produced via dedicated perennial herbaceous plant species, or short-rotation woody crops. Other sources of biomass are organic waste and residues such as those from straw, wood waste from the pulp and paper industry, and forestry residues. The use of waste biomass to produce fuels or products offers a way of creating value for society by displacing fossil fuels with material that would typically decompose over time and has no value in its current state [29].

\subsection{Triglycerides}

Oils and fats are triglycerides consisting of glycerol, saturated, and unsaturated fatty acids. The chain length varies between $\mathrm{C} 8$ and $\mathrm{C} 20$, however 16, 18, and 20-carbon chain lengths are the most common (their chain length ranges between C8 and C20, but 16, 18 and 20 carbons are the most common). Vegetable and animal raw materials are the sources of oils and fats. However, soybean, palm, rapeseed, and sunflower oil are the most dominant feedstock used globally for oil production, the most important in terms of worldwide use and production [44]. Currently, vegetable oils are 
being used for the production of biodiesel by treatment with alcohol of low molecular weight (usually ethanol or methanol) in the presence of an alkaline catalyst (usually $\mathrm{NaOH}$ or $\mathrm{KOH}$ ) to produce esters and glycerin. Chemically, biodiesel is called a methyl ester if the alcohol used is methanol, and ethyl ester if ethanol is used. Vegetable oils have two reactive sites, the double bond in the unsaturated fatty acid chain and the acid group of the fatty chain. Both these reactive sites make vegetable oil a suitable substitute for biodiesel production [36]. Like sugar and starch crops, oilseed crops are characterized by low yield (maximum glucose recoveries of $75 \%$ and $88 \%$ ) and the high use of inputs [57]. In the future however, food crops including oil crops will become highly controversial to be utilized for fuel production. Non-edible crops like Jatropha curcas and Salicornia bigelovii, which require lower inputs and are better suited to marginal lands, will then become the most widespread oil crops for biorefinery purposes, especially in dry and semiarid regions [58,59]. Waste vegetable oil is readily available from the food industry, processing plants, and households. These can also serve as valuable options for procuring feedstock and are a positive step in developing a circular economy [48].

\subsection{Mixed Organic Fractions}

Manure, proteins, and residues from fresh fruit and vegetable industries fall into this category and can be collectively called Organic Fraction of Municipal Solid Waste (OFMSW). The physical and chemical characteristics of these kinds of biomasses are varied and cannot be categorized due to their highly heterogeneous chemical compositions. Certain streams such as sewage sludge, manure from dairy and cattle farms, and residues from food processing have a very high moisture content (up to $70 \%$ ), thereby making them less attractive for high temperature processes such as gasification [60]. Feedstock with high moisture content are more suited for anaerobic digestion to generate biogas. Other streams, such as OFMSW mixed with paper, cardboard, and plastics usually represent a high potential for energy recovery. The different properties and characteristics of the biomass waste require different conversion technologies, and hence an interconnected network of processing for biorefineries seems to be an ideal solution for this type of feedstock.

\subsection{Proteins}

Polypeptide chains are the structural elements of proteins. Polypeptide chains, when combined with fats, form lipoproteins, and when combined with polysaccharides form [61]. The molecular weights of proteins can vary from thousands to millions of Dalton. There are two general classes of protein molecules: fibrous and globular proteins. Fibrous proteins are typically elongated and insoluble. Globular proteins are generally compact, soluble, and spherical in shape. In more complex proteins, spherical units sometimes joined by non-covalent forces can form larger structures that have a more defined shape. Proteins can be found in plants and animals. For human consumption, cereals (e.g., wheat, barley and sorghum) and legumes (green peas, lentils, beans and chickpeas) are the primary sources of non-animal-based proteins. Increased demand for proteins has led to the commercial production of soy-, wheat-, casein-, and whey-based proteins, used both in food and non-food industries [61]. Biomasses such as algae and grass have been studied for their protein use $[62,63]$. Apart from these protein resources, the biorefinery approach is encouraging the utilization of residual streams such as the recovery of protein from the press cakes left behind after recovering oil from oilseeds of sunflower seeds or rapeseeds [64,65].

\section{Processes}

The aim of technological processes in biorefining is to depolymerize and deoxygenate the biomass to convert it into valuable products within a biorefinery approach. Often, several technological processes must be applied in parallel, or subsequently. These processes are also called fractionation process of the biomass/feedstock, since they ensure that the carbohydrates, sugar, lipids, etc., can be made available for further refining. Broadly, these processes can be divided into five categories: thermochemical, hydrothermal, biochemical, mechanical/physical and chemical processes. 


\subsection{Thermochemical Processes}

The two main thermochemical processes for converting biomass into energy and chemical products are gasification and pyrolysis. Gasification involves heating the biomass at a high temperature $\left(>700^{\circ} \mathrm{C}\right)$ with low oxygen levels to produce a mixture of $\mathrm{H}_{2}, \mathrm{CO}, \mathrm{CO}_{2}$ (collectively known as syngas) and $\mathrm{CH}_{4}$ [39]. Syngas can be used directly for electricity, or as a chemical platform for the production of fuels (FT-fuels, dimethyl ether, ethanol, isobutene, etc.) or chemicals (alcohols, organic acids, ammonia, methanol, etc.). Pyrolysis breaks down biomass at temperatures between $300-600{ }^{\circ} \mathrm{C}$ and in the absence of oxygen. The three products obtained after pyrolysis are pyrolytic oil (liquid), solid charcoal, and light gases [66]. Based on process conditions during pyrolysis, the product yields can be varied. However, the most desirable product after pyrolysis is bio-oil as it is a precursor to obtaining various fuels and chemicals downstream. [29]. Bio-oil's application as a transportation biofuel is problematic and its use as a source for chemical production is under-developed [67]. Direct combustion is the oldest and most common thermochemical process; biomass is burned in an oxygen-rich environment, primarily for the production of heat. However, the losses and inefficiencies of this technology have led to advances in other, more efficient processing pathways.

\subsection{Low-Temperature Processes}

Hydrothermal treatment is one of the most commonly used lower temperature processes, which typically involves cooking biomass in water at high temperatures $\left(120-250^{\circ} \mathrm{C}\right)$, with residence times ranging from 10-50 mins, and under high pressure (up to 20 bar) [68]. Liquid hot water and uncatalyzed steam explosion are the two most commonly used subcategories of hydrothermal pretreatment [68]. Generally, this method is applied at a large scale and does not require prior size reduction, thus reducing capital and operating costs [69]. However, according to Hosseini and Shah, a $50 \%$ increase in energy efficiency can be achieved when the size of wood chips is reduced [70].

Hydrothermal treatment removes only small amounts of lignin (the acid soluble fraction), and changes the lignin structure by melting, coagulating and subsequently depolymerizing the cellulose fibers. Therefore, it is not possible to extract lignin in its functional form from hydrothermally pretreated solids [71]. However, hydrothermal treatment greatly increases the available surface area of cellulose (by non-chemical swelling), which significantly enhances possible sites for enzyme activity. The severity of pretreatment can be summarized by a single factor called $R_{O}\left(R_{O}=t \exp ((T-100) / 14.75)\right.$, which links the effects of time, $\mathrm{t}(\mathrm{min})$ and temperature, $\mathrm{T}\left({ }^{\circ} \mathrm{C}\right)$ [71]. Steam pretreatment, due to its high severity, (above 3.0) is one of the most used methods for creating high concentrations of sugar degradation products. However, a high process severity (above 4.0 ) also leads to the formation of inhibitors such as furfural (from dehydration of pentoses) and 5-hydroxyl-methyl-furfural (from dehydration of hexoses). Both degradation products and acetic acid (along with small amounts of other organic acids-levulinic and formic) formed during the treatment inhibit yeast. At higher concentrations, formic acid is more inhibitory than levulinic acid, which, in turn, is more inhibitory than acetic acid. The concentrations at which these compounds become inhibitory depends on the severity of the pretreatment. Larsson et al., reported that acetic acid, formic acid, and levulinic acid concentrations up to $100 \mathrm{mmol} / \mathrm{l}$ increase the ethanol yield, however, higher concentrations than this resulted in a decrease in the ethanol yield and other fermenting microorganisms when present in high concentrations [72]. Other by-products include the lignin degradation products present in the form of long-chain polymers [73]. Although these are seen as degradation products, when the process is targeting ethanol and biogas, however, in the biorefinery context, these (levulinic, and formic, acetic, and other organic acids) might as well be the target products due to their high market value. The kinetics of the process can also be designed to maximize their production and neglect the formation of the previously envisaged products like ethanol and biogas.

High-temperature treatments (upto $230^{\circ} \mathrm{C}$ ) require short residence time (as low as a few seconds), and low temperatures treatments $\left(150-180^{\circ} \mathrm{C}\right.$ ) require long residence time (up to a few hours), a trade-off amongst which can be calculated using the severity factor [74]. Generally, the established 
convention in the literature is that hydrothermal pretreatment does not include steam explosion. The distinction lies in the gradual heating and cooling before and after pretreatment respectively, a critical operational procedure, which is lacking in the case of steam explosion [68]. Hydrothermal treatment is gaining special interest as a pretreatment method for the ethanol industry, since it does not require any chemicals, and is simple in operation.

\subsection{Biochemical Processes}

Biochemical processes are carried out at relatively low temperatures (below $80^{\circ} \mathrm{C}$ ) as compared to thermochemical pathways. The most common types of biochemical processes are fermentation, enzymatic hydrolysis, and anaerobic digestion. During fermentation, the substrate is converted into alcohols and organic acids due to the action of microorganisms and/or enzymes. Anaerobic digestion occurs in the absence of oxygen at temperatures around $35-55^{\circ} \mathrm{C}$, where bacteria breakdown the biodegradable organic content of the substrate to form methane and carbon dioxide. Due to the large demand for liquid fuel for transportation, and the early discovery of sugarcane to ethanol pathway (and, subsequently, corn to ethanol pathways), ethanol is the most common fermentation product, but the production of other chemical compounds (e.g., hydrogen, methanol, succinic acid) is a growing area of research. Fermentation has been a well-known process from as early as the 1870s, when Louis Pasteur demonstrated that microorganisms can convert sugars to alcohol in the absence of oxygen. Despite the early knowledge of the process, the utilization of sugars for fuel production has been a rather slow and with fluctuations. Today, biochemical processes have evolved to use genetically modified microorganisms to produce targeted compounds. C6 sugars, however, remain the most frequent fermentation substrates, while pentose (sugars from hemicellulose), glycerol and other hydrocarbons require customized fermentation organisms to enable their conversion to ethanol and other products [75]. The main product from anaerobic digestion is biogas, which is a mixture of methane, carbon dioxide, and other gases. Methane from anaerobic digestion can be upgraded to $97 \%$ purity, which can be used as a substitute for natural gas [76].

Pretreatment is a pre-requisite step for converting lignocellulosic biomasses to sugars for fermentation to ethanol, while other products requires specifically designed processes. It involves the breaking up of a naturally resistant carbohydrate-lignin shield that limits the accessibility of enzymes to cellulose and hemicellulose. The pretreatment of lignocelluloses by physical/chemical/enzymatic means creates a stream rich in monomeric sugars, which can be converted biologically into fermentation products such as ethanol and/or biogas [77].

\subsection{Mechanical Processes}

Mechanical processes do not change the state or the composition of biomass; they only perform size reduction or separation of feedstock components [78]. These are typically the first steps in a biorefinery network because biomass utilization requires small particles to provide a large surface area for the conversion process to be efficient [69]. Biomass size reduction is achieved by either cutting or commuting processes that significantly change the particle size, shape, and bulk density of biomass. Separation processes segregate the components of the substrate, while extraction methods extract and concentrate valuable compounds from bulky, heterogeneous substrates.

\subsection{Chemical Processes}

Chemical processes can alter the chemical structure of the feedstock at molecular levels, when the biomass reacts with other compounds during the presence of catalysts. The most common chemical processes in biomass conversion are enzymatic hydrolysis and transesterification. In hydrolysis, acids and alkalis are used to depolymerize polysaccharides to monomeric sugars (e.g. cellulose to glucose). In transesterification vegetable oil is converted to methy or ethyl esters of fatty acids, commonly known as biodiesel. This process also coproduces glycerin, a chemical compound with 
diverse commercial uses [44]. Other important and common chemical reactions in biorefining are Fisher-Tropsch synthesis, methanisation, and steam reforming [79].

\section{Products}

The products of biorefinery systems can be grouped in two broad categories: chemicals and energy. Energy products are used to provide electricity, heat or transportation services, while material products are used for their chemical or physical properties. In some cases, a further distinction is required because some products, like bio-hydrogen or bioethanol, might be used either as fuels or as a chemical compound in chemical synthesis.

The fundamental idea is to make products from a biorefinery similar to those products that are currently being made available from petrochemical refineries. Biomass in this context proved to be an alternative to using fossil fuels while providing significant environmental benefits and similar downstream benefits, such as petrochemical refineries. The most important energy products that can be obtained from biorefineries are:

(a) Gaseous biofuels (biogas, syngas, hydrogen, bio-methane);

(b) Solid biofuels (pellets, lignin, charcoal);

(c) Liquid biofuels for transportation (bioethanol, biodiesel, FT-fuels, bio-oil).

The most important chemical and material products are:

1. Chemicals (fine chemicals, building blocks, bulk chemicals);

2. Organic acids (succinic, lactic, levulinic and other sugar derivatives);

3. Polymers and resins (starch-based plastics, phenol resins, furan resins);

4. Biomaterials (wood panels, pulp, paper, cellulose);

5. Food and animal feed (protein rich);

6. Fertilizers;

7. Biopolymers (example: polylactic acid).

The current manufacturing of bulk chemicals is based predominantly on crude oil and natural gas feedstock. The petrochemicals industry has developed alongside oil refining, thriving by exploiting cheap and readily abundant oil reserves. The petrochemical sector accounts for $14 \%$ of daily global oil use and around $8 \%$ of gas $[80,81]$. With this large dependence on hydrocarbons, the petrochemical industries have integrated with oil and gas refineries to evolve into large, flexible, highly efficient manufacturing units that maximize their co-location benefits to exploit the various energy and raw material streams for cost-effective chemical production. Petrochemical complexes produce primary chemical intermediates such as ethylene, propylene, butylene, and aromatics, which are further converted into intermediates for the plastics, textiles, solvents, and detergent markets. Ethylene by volume is the largest produced intermediate chemical by volume, with over 75 million tonnes produced globally every year [19]. Bioethanol can be dehydrated into ethylene, which can, in turn, be converted to propylene, butylene, and aromatics, thereby giving a glimpse of how biorefinery based models can seamlessly be integrated into existing markets.

\section{Types of Biorefineries}

An increased focus on studying biomass utilization and product creation from biomass, gives rise for the need to classify the types of biorefineries. With the current knowledge of the types of biofuels, feedstock, and products, a few classifications can be made based on:

1. Raw material input (i.e., Green Biorefinery, Crop Biorefinery, Lignocellulosic Feedstock Biorefinery, Marine Biorefinery);

2. Type of technology (i.e., Two Platform Concept, Thermochemical Biorefinery); 
3. Status-of-technology (Conventional and Advanced Biorefineries, 1st and 2nd Generation Biorefineries);

4. Main or intermediate product produced (Syngas Platform, Sugar Platform, Lignin Platform).

In order to develop a distinct and acceptable classification system, the important factors to take into account are [82]:

(a) A broad definition encompassing the biorefinery area which is more accessible for different stakeholders;

(b) Improved overall understanding of the advantages of biorefinery processing (multi-step and integrated process) over single-product processes;

(c) Market implementation and acceptance of these concepts into the global community of scientists.

The development of a proper classification system was one of the main tasks of IEA Bioenergy Task 42 on Biorefineries, and shows the first set of classifications done on the basis of feedstock and technology being used (see Table 2).

Table 2. Classification of a biorefinery.

\begin{tabular}{|c|c|c|c|c|}
\hline Type of Biorefinery & Feedstock & Processing Techniques & Products & References \\
\hline Green Biorefineries (GB) & $\begin{array}{l}\text { wet biomass: green grasses } \\
\text { and green crops, such as } \\
\text { lucerne and clover }\end{array}$ & $\begin{array}{l}\text { pretreatment, pressing, } \\
\text { fractionation, separation, } \\
\text { digestion }\end{array}$ & $\begin{array}{l}\text { Lactic acid, amino acids, ethanol, } \\
\text { proteins, biogas, dyes, pigments. }\end{array}$ & {$[29,83,84]$} \\
\hline Whole Crop Biorefineries (WCB) & $\begin{array}{l}\text { whole crop (including straw) } \\
\text { cereals such as rye, wheat, } \\
\text { and maize }\end{array}$ & $\begin{array}{l}\text { dry or wet milling, } \\
\text { biochemical conversion }\end{array}$ & $\begin{array}{c}\text { Syngas, sorbitol, glucose amine, } \\
\text { ethanol, biogas, ethylene glycol, } \\
\text { propylene glycol, glycerin }\end{array}$ & [84-87] \\
\hline $\begin{array}{l}\text { Lignocellulosic Feedstock } \\
\text { Biorefineries (LB) }\end{array}$ & $\begin{array}{l}\text { lignocellulosic-rich biomass: } \\
\text { e.g., straw, chaff, reed, } \\
\text { miscanthus, wood }\end{array}$ & $\begin{array}{l}\text { pretreatment, chemical and } \\
\text { enzymatic hydrolysis, } \\
\text { fermentation, separation }\end{array}$ & $\begin{array}{c}\text { Energy, syngas, methanol, } \\
\text { levulinic acid, ethanol, acetic acid, } \\
\text { lactic acid, furfural, } \\
\text { 5-hydroxymethyl-furfural (HMF) }\end{array}$ & {$[3,45,69,88]$} \\
\hline Marine Biorefineries (MB) & $\begin{array}{l}\text { aquatic biomass: microalgae } \\
\text { and macroalgae (seaweed) }\end{array}$ & $\begin{array}{l}\text { cell disruption, product } \\
\text { extraction and separation }\end{array}$ & $\begin{array}{l}\text { Protein for fish farming, dietary or } \\
\text { health food, lipids, especially } \\
\text { high-value fatty acids linoleic acid } \\
\text { and g-linolenic acid. }\end{array}$ & [89-91] \\
\hline
\end{tabular}

Green biorefineries are gaining traction and increasing in popularity especially in northern European countries. Green biomass is separated into a fiber-rich press cake and protein-rich juice [87]. The bulk chemical are in the press cake (e.g., cellulose, starch and dyes) and green juice contains the proteins and free amino acids $[87,92]$. The green juice is a potential raw material for the production of high quality fodder and cosmetic proteins, human nutrition, chemicals (e.g., lactic acid and lysine), or can alternatively be used as a substrate for biogas production [87]. Another advantage of the green biorefinery is its ability to utilize versatile and abundant types of green biomasses [83]. A consolidated review of the types of green biorefineries and their processes is presented in Table 3.

Waste biorefinery predominantly utilizes food or municipal solid waste or "kitchen waste" as its feedstock. Since the feed for this biorefinery is labelled as waste streams from other industries, hence they are called waste 'utilizing' biorefineries. While different types of waste streams can be combined in one biorefinery, it is important to ensure that the input stream to biorefineries is structurally and compositionally similar, such that the processing steps can handle a certain degree of heterogeneity in the feedstock. Biorefineries utilizing waste/residual streams are shown in Table 4. 
Table 3. Green biorefineries distinguished based on feedstock.

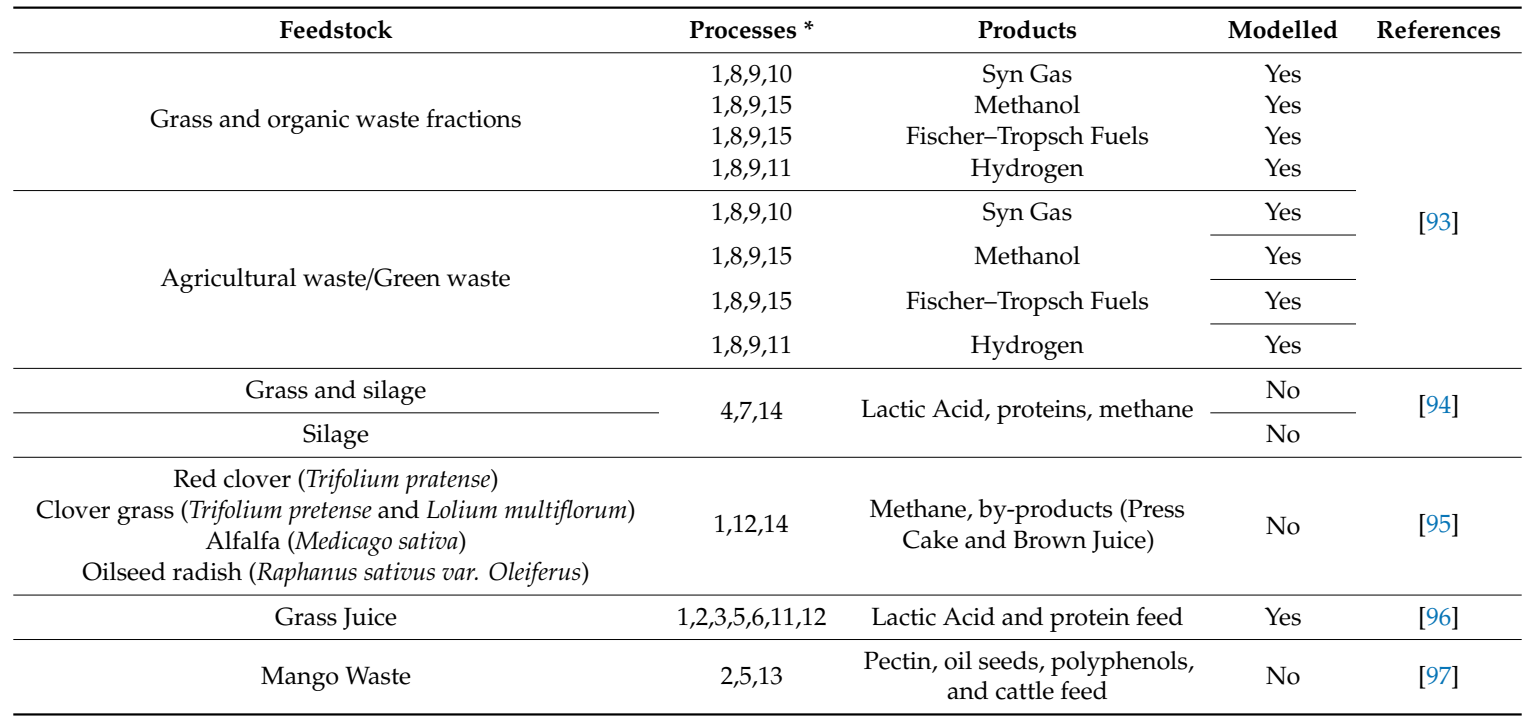

* 1) Pretreatment, 2) Drying, 3) Dilute Acid Pretreatment, 4) Washing, 5) Size Reduction, 6) Enzymatic Hydrolysis, 7) Filtration, 8) Gasification, 9) Compression, 10) Methanation, 11) Adsorption, 12) Fermentation, 13) Separation, 14) Anaerobic digestion, 15) Distillation.

Table 4. Different types of waste biorefineries categorized based on their feed.

\begin{tabular}{|c|c|c|c|c|}
\hline Feedstock & Processes ** & Products & Modelled & References \\
\hline \multirow{3}{*}{ Sludge and manure } & $1,4,5,6$ & Syn Gas & Yes & \multirow{8}{*}{ [93] } \\
\hline & $1,4,5,15$ & Methanol & Yes & \\
\hline & $1,4,5,15$ & Fischer-Tropsch Fuels & Yes & \\
\hline \multirow{8}{*}{ Municipal Solid Waste } & $1,4,5,7$ & Hydrogen & Yes & \\
\hline & $1,4,5,6$ & Syn Gas & Yes & \\
\hline & $1,4,5,15$ & Methanol & Yes & \\
\hline & $1,4,5,15$ & Fischer-Tropsch Fuels & Yes & \\
\hline & $1,4,5,7$ & Hydrogen & Yes & \\
\hline & $3,7,14$ & Biogas & Yes & [98] \\
\hline & $1,3,5,12,13,15$ & Fischer-Tropsch Fuels, olefins, and aromatics & Yes & [99] \\
\hline & 1,14 & Energy & No & [100] \\
\hline \multirow{2}{*}{ Food Waste } & $2,3,11,13,14$ & Biogas and hydrogen & Yes & [101] \\
\hline & $2,7,9,10,11,13,14$ & Lactic acid and biogas & Yes & [102] \\
\hline Slaughter Waste & $2,11,13,14$ & Polyhydroxyalkanoate (PHA) & No & [103] \\
\hline Waste Oil & $1,8,13$ & Fatty Acid Methyl Esters (FAME) and glycerol & Yes & {$[104,105]$} \\
\hline
\end{tabular}

** 1) Pretreatment, 2) Hydrolysis, 3) Size Reduction, 4) Gasification, 5) Compression, 6) Methanation, 7) Adsorption,

8) Transesterification, 9) Saccharification, 10) Simultaneous Saccharification and Fermentation, 11) Fermentation, 12)

Heat Steam Recovery, 13) Separation, 14) Anaerobic digestion, 15) Distillation.

Whole-crop biorefinery utilizes crops and agriculture residue for biofuel and bio-product generation. Cereals were considered the early feedstock for whole crop biorefinery due to their rich starch content [52]. However, with the debate of food vs. fuel and advances in processing lignocellulose, agricultural residue is the preferred source of feed for whole crop biorefineries. Moreover, combining both the harvest from crops while processing the grain appears to be a more profitable option as opposed to just performing one of these tasks independently [106]. Table 5 shows whole-crop biorefineries utilizing different types of feed.

The lignocellulosic biorefineries are generally suited for producing products at an industrial scale, and utilize a variety of raw material (e.g., straw, reed, grass, wood, paper-waste) available at low prices [92]. It is also a better alternative to food crops since lignocellulosic feedstock does not compete with edible crops such as corn and sugarcane (see Table 6).

Marine species, such as microalgae, macroalgae, and seaweeds, have long been of interest due to their ability to grow in saline water, non-competence with land for growth, and potential to produce bio-products, and biofuels. The literature for the types of marine species feasible for utilization in a 
biorefinery context is very large and ever-growing. Table 7 highlights some of the species that have been isolated and explored for their use in a biorefinery.

Table 5. Whole-crop biorefineries utilizing various types of crop and crop by-products.

\begin{tabular}{|c|c|c|c|c|}
\hline Feedstock & Processes *** & Products & Modelled & References \\
\hline Yellow Poplar & $3,11,15$ & Ethanol, Biogas & Yes & [107] \\
\hline $\begin{array}{c}\text { Saccharified Liquefied Cornstarch (SLCS) } \\
\text { with moisture content of approximately } 60 \%\end{array}$ & $6,12,15$ & Ethanol and methane & Yes & [108] \\
\hline Wheat Straw & $\begin{array}{c}1,4,5,16 \\
1,6,7,12,16 \\
1,6,10,12,15 \\
1,6,12,16 \\
1,10,12,16\end{array}$ & $\begin{array}{c}\text { Butanol } \\
\text { Bioethanol, hydrogen, and biogas } \\
\text { Butyric Acid } \\
\text { Ethanol } \\
\text { Biomethane, ethanol, electricity and phenols }\end{array}$ & $\begin{array}{l}\text { Yes } \\
\text { No } \\
\text { Yes } \\
\text { Yes } \\
\text { No }\end{array}$ & $\begin{array}{l}{[109]} \\
{[110]} \\
{[111]} \\
{[112]} \\
{[113]}\end{array}$ \\
\hline Sugarcane & $\begin{array}{c}2,8,14 \\
1,4,5,12,16 \\
5,12,13,16\end{array}$ & $\begin{array}{l}\text { Ethanol, electricity, gypsum, fertilizers, } \\
\text { Electricity, ethanol, animal feed } \\
\text { Ethanol, sugar, power, and n-butanol, } \\
\text { acetone- butanol-ethanol }\end{array}$ & $\begin{array}{l}\text { No } \\
\text { Yes } \\
\text { Yes }\end{array}$ & $\begin{array}{c}{[22]} \\
{[114]} \\
{[115]}\end{array}$ \\
\hline
\end{tabular}

*** 1) Pretreatment, 2) Drying, 3) Dilute Acid Pretreatment, 4) Hydrolysis, 5) Size Reduction, 6) Enzymatic Hydrolysis, 7) Dark Fermentation, 8) Gasification, 9) Adsorption, 10) Saccharification, 11) Simultaneous Saccharification and Fermentation, 12) Fermentation, 13) Dehydration, 14) Heat Steam Recovery, 15) Separation, 16) Distillation.

Table 6. Various lignocellulose based biorefineries.

\begin{tabular}{|c|c|c|c|c|}
\hline Feedstock & Processes $t$ & Products & Modelled & References \\
\hline \multirow{8}{*}{ Corn Stover } & 1,18 & Ethanol & No & [116] \\
\hline & $1,7,19,25$ & Ethanol, succinic acid, acetic acid, electricity & Yes & [117] \\
\hline & $1,5,14,19,25$ & Biomethane, ethanol, electricity and phenols & No & [113] \\
\hline & $1,17,19,20,22,25$ & Gypsum, methane and ethanol & Yes & [118] \\
\hline & 3,17 & Phthalic Anhydride & Yes & [119] \\
\hline & $1,17,19,23,25$ & Ethanol & Yes & [120] \\
\hline & $10,21,23$ & Naphtha and diesel range fuels & Yes & [121] \\
\hline & $1,6,7,17,19,25$ & Bioethanol & Yes & [122] \\
\hline Corn & $3,18,25$ & Ethanol & Yes & [123] \\
\hline Yellow onion (allium cepa) & 2,24 & Quercetin, biogas & No & \multirow{2}{*}{ [124] } \\
\hline Birch Forest (betula spp.) & 15,16 & Electricity, betulin & No & \\
\hline \multirow{4}{*}{ Wood and forest waste } & $1,9,11,12$ & Syn Gas & Yes & \multirow{4}{*}{ [93] } \\
\hline & $1,9,11,25$ & Methanol & Yes & \\
\hline & $1,9,11,25$ & Fischer-Tropsch Fuels & Yes & \\
\hline & $1,9,11,13$ & Hydrogen & Yes & \\
\hline Forest Residue & $9,21,23,25$ & Methanol, Dimethyl Ether, ammonia, Fischer Tropsch Fuels & No & [125] \\
\hline Forest Residue and straw & 9,23 & Biohydrogen & Yes & [126] \\
\hline Pine & $9,11,21,23$ & Methanol & No & [127] \\
\hline \multirow{7}{*}{ Lignocellulose } & $10,21,23,25$ & Gasoline, diesel, Fischer Tropsch fuel, and biochar & Yes & [128] \\
\hline & $6,9,23,25$ & Gasoline and Methanol intermediates & Yes & [129] \\
\hline & $10,11,13,21,23,25$ & Gasoline, diesel, and bio-oil & Yes & [130] \\
\hline & $10,21,23$ & Ethylene and propylene & Yes & [131] \\
\hline & $6,10,23,25$ & Gasoline and diesel & Yes & [132] \\
\hline & $1,19,23,24$ & Acetone, butanol, ethanol, biogas, and hydrogen & Yes & [133] \\
\hline & $1,5,6,13,19,23$ & Butanol & Yes & [134] \\
\hline Salicornia bigelovii & $1,2,3,4,5,7,18,24,25$ & Ethanol, and biogas & No & [59] \\
\hline Dried Oil Palm & 1,18 & Furfural, ethanol and lignin & No & [17] \\
\hline Jatropha curcas & $6,10,20,23,25$ & Jet Fuel (light gases, naphtha, jet fuel, and diesel) & Yes & [135] \\
\hline Switch Grass & $1,5,14,19,24$ & Bioethanol, biomethane, electricity, phenols & No & [113] \\
\hline Tunisian Alfa (Stipa tenassicima) & $1,7,17,19,23,25$ & Bioethanol & No & [136] \\
\hline Sunflower seed & $7,8,19$ & $\begin{array}{l}\text { Poly(3-hydroxybutyrate) PHB, levulinic acid, protein isolate } \\
\text { and antioxidants }\end{array}$ & No & [64] \\
\hline Wheat Barn & $1,16,19$ & Lactic Acid, lignin fraction & No & [137] \\
\hline Palm oil fronds & $6,17,25$ & Bioplastic, poly(3-hydroxybutyrate) PHB & Yes & [138] \\
\hline Bamboo & $5,7,19$ & Xylitol, Lactic Acid, succinic acid, biomethane, ethanol & No & [139] \\
\hline Triticale straw & 14 & Electricity & No & [140] \\
\hline
\end{tabular}

† 1) Pretreatment, 2) Drying, 3) Dilute Acid Pretreatment, 4) Washing, 5) Hydrolysis, 6) Size Reduction, 7) Enzymatic Hydrolysis, 8) Microbial Biochemical Conversion, 9) Gasification, 10) Pyrolysis, 11) Compression, 12) Methanation, 13) Adsorption, 14) Combustion, 15) Incineration, 16) Extraction, 17) Saccharification, 18) Simultaneous Saccharification and Fermentation, 19) Fermentation, 20) Dehydration, 21) Heat Steam Recovery, 22) Evaporation, 23) Separation, 24) Aerobic Digestion, 25) Distillation. 
Table 7. Marine biorefineries distinguished based the different marine species of microalgae and macroalgae.

\begin{tabular}{|c|c|c|c|c|}
\hline Feedstock & Processes $\ddagger$ & Products & Modelled & References \\
\hline Microalgae & $3,6,10,11,15$ & High value products, biodiesel, bioethanol and biogas & No & [141] \\
\hline Microalgae (Chlorella strain) & $1,5,13,14,15,16$ & Naphtha, biogas, renewable diesel blendstock, AD digestate & Yes & [142] \\
\hline Brown macroalgae (Laminaria japonica) & $4,7,15$ & Hydrogen and methane & No & [143] \\
\hline Microalgae A. maxima & 7,15 & \multirow{4}{*}{ Hydrogen and methane } & No & [144] \\
\hline Lipid extracted microalgae (Scenedesmus spp.) & 7,15 & & No & [145] \\
\hline Microalga Chlorella (Pyrenoidosa spp.) & $7,8,9,15$ & & No & [146] \\
\hline Microalgae (Nannochloropsis oceanica spp.) & $2,7,8,9,15$ & & No & \\
\hline Neochloris oleoabundans & \multirow{4}{*}{$6,11,12$} & \multirow{4}{*}{ Lipid, protein and starch } & No & \multirow{4}{*}{ [62] } \\
\hline Chlorella sorokiniana & & & No & \\
\hline Tetraselmis suecica & & & No & \\
\hline Nannochloropis oculata & & & No & \\
\hline Microalgae & $6,11,16$ & $\begin{array}{c}\text { Bioethanol, heat and power, biodiesel (from microalgae oil), } \\
\text { and glycerol }\end{array}$ & No & [21] \\
\hline
\end{tabular}

‡ 1) Pretreatment, 2) Microwave Pretreatment, 3) Drying, 4) Dilute Acid Pretreatment, 5) Washing, 6) Harvesting, 7)

Dark Fermentation, 8) Centrifugation, 9) Photo fermentation, 10) Transesterification, 11) Extraction, 12) Digestion,

13) Fermentation, 14) Separation, 15) Anaerobic Digestion, 16) Distillation.

These tables (Tables 2-7) describe the literature categorized on types of biorefineries and the processes mentioned and modelled (in most cases). Some other papers that deserve mention but have not detailed the unit processes in their description include a biorefinery based on palm oil which includes biomass gasification and catalytic technologies [147]. Sammons et al., combined process and economic modelling under a process systems approach to design an optimal product [12]. Laser, Jin, et al., developed seven process designs co-producing ethanol, Fischer Tropsch fuels, hydrogen, methane, and power, and three processes co-producing animal feed protein from switchgrass [148]. Dale et al., designed a biorefinery for protein feeds with fuels and chemicals [92]. Pinatti et al., described a biorefinery concept with eleven thermochemical processing routes and one biological route [149]. Bao et al., used an optimization-based approach to design integrated biorefineries [150]. Sharma et al., used a mixed-integer linear programming (MILP) model to obtain a multi-product, multi-platform biorefinery [151]. Tay et al., maximized economic performance coupled with minimal environmental impact in a fuzzy mathematical programming to obtain a biorefinery [14].

\section{Conclusions}

While the process design of biorefineries has gained more traction, there is still a long way to go before it can catch up with petrochemical process designs, which are readily available, intricately designed, and have undergone several decades of reiterative modelling exercise owing to active industrial collaboration. The mismatch between the number of process designs available for biorefineries and petrochemical refineries can further be attributed to the commercialization of the petrochemical industry, which has far more large-scale facilities that are operational as compared to industrial scale biorefineries. The path to developing biorefinery process design begins by using software that has traditionally been used for petrochemical refinery designing. This means that unit operations for processing biomass are currently not available by default in software libraries. Additionally, the chemical properties of biomass building blocks and intermediate biochemicals (due to their complex structures) have to be defined by users. These problems, compounded with limited input from the industry, have led researchers to rely on the published literature in order to design biorefineries. While some of the published literature details each unit operation and its respective operating conditions, others, for the most part, design biorefineries with a rather top view approach, aimed at demonstrating the economic feasibility of a particular biomass-processing pathway. Finding detailed and replicable process designs for biorefineries is arduous and many times not accurate, which led to the necessity of this study. 
The aim of consolidating the literature describing process design of biorefineries is threefold. Firstly, to identify and list the unit operations mentioned in the literature that can describe biorefinery process designs. In this step, all the unit operations available in the relevant publication are listed, presenting an early look into the processing pathway and its level of depth. Secondly, by categorizing these process designs based on the type of biomass, we can compare how processes are similar or different for a particular biomass processing and what products they yield. It would have been ideal if we could list the operating conditions of each unit operation, such as feed input, product quantities, and their yields. However, these are rather important details and require a more focused description, which leads us to the third aim of this paper. Finally, by mentioning whether the process design has been modelled or not, we are letting the readers know if they can expect further operational details of the process design. If the process design has been modeled, then data on fed input and output, yields, energy balance, reaction kinetics, etc., will be available along with its methodology in the respective publications. However, if the process has not been modeled, then it is safe to assume that only a blueprint of the process design, with fewer operational details, will be available. Single-feedstock to single-product pathway processes have not been considered as a biorefinery. Multiple feedstock or multiple products process designs are taken as the minimum satisfactory condition to be considered a biorefinery, which falls in agreement with the academically accepted definition of a biorefinery.

In the future, we aim to work towards describing more details of each unit operation, so that comparisons can be made between the replicability of each unit operation, allowing for more comprehensive techno-economical comparisons between processing pathways. Critical examination of each processing pathway can, in turn, lead to more robust process designs for biomass utilization.

Author Contributions: All of the authors were involved in preparing this manuscript. All authors have read and agreed to the published version of the manuscript.

Funding: This research received no external funding.

Acknowledgments: This research work was funded by the Cooperative Agreement between the Masdar Institute of Science and Technology, Abu Dhabi, UAE and the Massachusetts Institute of Technology (MIT), Cambridge, MA, USA-Reference project BIOREFINERY-02/MI/MI/CP/11/07633/GEN/G/00 for work under the Second Five Year Agreement.

Conflicts of Interest: The authors declare no conflict of interest.

\section{References}

1. Kamm, B.; Kamm, M. Biorefineries-Multi Product Processes. In White Biotechnology; Springer: Berlin/Heidelberg, Germany, 2007.

2. Pham, V.; El-Halwagi, M. Process synthesis and optimization of biorefinery configurations. AIChE J. 2012, 58, 1212-1221. [CrossRef]

3. Humbird, D.; Davis, R.; Tao, L.; Kinchin, C.; Hsu, D.; Aden, A. Process Design and Economics for Biochemical Conversion of Lignocellulosic Biomass to Ethanol: Dilute-Acid Pretreatment and Enzymatic Hydrolysis of Corn Stover; National Renewable Energy Lab.: Golden, CO, USA, 2011.

4. Lino, F.A.M.; Ismail, K.A.R. Energy and environmental potential of solid waste in Brazil. Energy Policy 2011, 39, 3496-3502. [CrossRef]

5. Zhang, C.; Su, H.; Baeyens, J.; Tan, T. Reviewing the anaerobic digestion of food waste for biogas production. Renew. Sustain. Energy Rev. 2014, 38, 383-392. [CrossRef]

6. Bothast, R.J.; Schlicher, M.A. Biotechnological processes for conversion of corn into ethanol. Appl. Microbiol. Biotechnol. 2005, 67, 19-25. [CrossRef]

7. Brown, D.; Li, Y. Solid state anaerobic co-digestion of yard waste and food waste for biogas production. Bioresour. Technol. 2013, 127, 275-280. [CrossRef]

8. Tao, L.; Schell, D.; Davis, R.; Tan, E.; Elander, R.; Bratis, A. NREL 2012 Achievement of Ethanol Cost Targets: Biochemical Ethanol Fermentation Via Dilute-Acid Pretreatment and Enzymatic Hydrolysis of Corn Stover; National Renewable Energy Lab.: Golden, CO, USA, 2014. 
9. Tula, A.K.; Eden, M.R.; Gani, R. Process synthesis, design and analysis using a process-group contribution method. Comput. Chem. Eng. 2015, 81, 245-259. [CrossRef]

10. Ashraf, M.T.; Torres, A.I.; Cybulska, I.; Fang, C.; Thomsen, M.H.; Schmidt, J.E.; Stephanopoulos, G. Optimization of Lignocellulosic Waste Biorefinery using Multi-Actor Multi-Objective Mathematical Framework. In Proceedings of the 26th European Symposium on Computer Aided Process Engineering; Elsevier: Portorož, Slovenia, 2016.

11. Moncada, J.; Matallana, L.G.; Cardona, C.A. Selection of process pathways for biorefinery design using optimization tools: A colombian case for conversion of sugarcane bagasse to ethanol, poly-3-hydroxybutyrate (PHB), and energy. Ind. Eng. Chem. Res. 2013, 52, 4132-4145. [CrossRef]

12. Sammons, N.E.; Yuan, W.; Eden, M.R.; Aksoy, B.; Cullinan, H.T. Optimal biorefinery product allocation by combining process and economic modeling. Chem. Eng. Res. Des. 2008, 86, 800-808. [CrossRef]

13. Lynd, L.R.; Wyman, C.; Laser, M.; Johnson, D.; Landucci, R. Strategic Biorefinery Analysis: Analysis of Biorefineries; National Renewable Energy Lab.: Golden, CO, USA, 2005.

14. Tay, D.; Ng, D. Fuzzy optimization approach for the synthesis of a sustainable integrated biorefinery. Ind. Eng. Chem. Res. 2011, 50, 1652-1665. [CrossRef]

15. Stuart, P.R.; El-Halwagi, M.M. Integrated Biorefineries: Design, Analysis, and Optimization; CRC Press: Boca Raton, FL, USA, 2012.

16. Kelloway, A.; Daoutidis, P. Process synthesis of biorefineries: Optimization of biomass conversion to fuels and chemicals. Ind. Eng. Chem. 2013, 53, 5261-5273. [CrossRef]

17. Raman, J.K.; Gnansounou, E. Furfural production from empty fruit bunch-A biorefinery approach. Ind. Crops Prod. 2015, 69, 371-377. [CrossRef]

18. Cheali, P.; Posada, J.A.; Gernaey, K.V.; Sin, G. Upgrading of lignocellulosic biorefinery to value- added chemicals: Sustainability and economics of bioethanol-derivatives. Biomass Bioenergy 2015, 75, 282-300. [CrossRef]

19. Werpy, T.; Petersen, G. Top Value Added Chemicals from Biomass Volume I-Results of Screening for Potential Candidates from Sugars and Synthesis Gas; National Renewable Energy Lab.: Golden, CO, USA, 2004.

20. Holladay, J.J.; White, J.F.; Bozell, J.J.; Johnson, D. Top Value Added Chemicals from Biomass-Volume II, Results of Screening for Potential Candidates from Biorefinery Lignin; Pacific Northwest National Lab.: Richland, NJ, USA, 2007.

21. Moncada, J.; Tamayo, J.A.; Cardona, C.A. Integrating first, second, and third generation biorefineries: Incorporating microalgae into the sugarcane biorefinery. Chem. Eng. Sci. 2014, 118, 126-140. [CrossRef]

22. Moncada, J.; El-Halwagi, M.M.; Cardona, C.A. Techno-economic analysis for a sugarcane biorefinery: Colombian case. Bioresour. Technol. 2013, 135, 533-543. [CrossRef]

23. Kumar, M.; Goyal, Y.; Sarkar, A.; Gayen, K. Comparative economic assessment of ABE fermentation based on cellulosic and non-cellulosic feedstocks. Appl. Energy 2012, 93, 193-204. [CrossRef]

24. Quintero, J.A.; Moncada, J.; Cardona, C.A. Techno-economic analysis of bioethanol production from lignocellulosic residues in Colombia: A process simulation approach. Bioresour. Technol. 2013, 139, 300-301. [CrossRef]

25. Klein-Marcuschamer, D.; Simmons, B.A.; Blanch, H.W. Techno-economic analysis of a lignocellulosic ethanol biorefinery with ionic liquid pre-treatment. Biofuels Bioprod. Biorefining 2011, 5, 562-569. [CrossRef]

26. Axelsson, L.; Franzén, M.; Ostwald, M.; Berndes, G.; Lakshmi, G.; Ravindranath, N.H. Perspective: Jatropha cultivation in southern India: Assessing farmers' experiences. Biofuels Bioprod. Biorefining 2012, 6, $246-256$. [CrossRef]

27. Baliban, R.C.; Elia, J.A.; Floudas, C.A. Biomass and natural gas to liquid transportation fuels: Process synthesis, global optimization, and topology analysis. Ind. Eng. Chem. Res. 2013, 52, 3381-3406. [CrossRef]

28. IEA. IEA Bioenergy Task 42 on Biorefineries: Co-Production of Fuels, Chemicals, Power and Materials from Biomass; IEA bioenergy task: Paris, France, 2010.

29. Cherubini, F. The biorefinery concept: Using biomass instead of oil for producing energy and chemicals. Energy Convers. Manag. 2010, 51, 1412-1421. [CrossRef]

30. Su, Y.; Zhang, P.; Su, Y. An overview of biofuels policies and industrialization in the major biofuel producing countries. Renew. Sustain. Energy Rev. 2015, 50, 991-1003. [CrossRef]

31. Kircher, M. Sustainability of biofuels and renewable chemicals production from biomass. Curr. Opin. Chem. Biol. 2015, 26, 26-31. [CrossRef] [PubMed] 
32. Biddy, M.J.; Scarlata, C.; Kinchin, C. Chemicals from Biomass: A Market Assessment of Bioproducts with Near-Term Potential; National Renewable Energy Lab.: Golden, CO, USA, 2016.

33. Preisig, H.A.; Wittgens, B. Thinking towards synergistic green refineries. Energy Procedia 2012, $20,59-67$. [CrossRef]

34. Sheldon, R.A. Green and sustainable manufacture of chemicals from biomass: State of the art. Green Chem. 2014, 16, 950-963. [CrossRef]

35. Jacobsen, N. Industrial symbiosis in Kalundborg, Denmark: A quantitative assessment of economic and environmental aspects. J. Ind. Ecol. 2006, 10, 239-255. [CrossRef]

36. Sims, R.E.; Mabee, W.; Saddler, J.; Taylor, M. An overview of second generation biofuel technologies. Bioresour. Technol. 2010, 101, 1570-1580. [CrossRef]

37. Stephen, J.; Sokhansanj, S.; Bi, X. The impact of agricultural residue yield range on the delivered cost to a biorefinery in the Peace River region of Alberta, Canada. Biosyst. Eng. 2010, 105, 298-305. [CrossRef]

38. Hess, J.; Wright, C.; Kenney, K. Cellulosic biomass feedstocks and logistics for ethanol production. Biofuels Bioprod. Biorefining 2007, 1, 181-190. [CrossRef]

39. Caputo, A.C.; Palumbo, M.; Pelagagge, P.M.; Scacchia, F. Economics of biomass energy utilization in combustion and gasification plants: Effects of logistic variables. Biomass Bioenergy 2005, 28, 35-51. [CrossRef]

40. Galbe, M.; Sassner, P.; Wingren, A.; Zacchi, G. Process engineering economics of bioethanol production. In Biofuels; Olsson, L., Ed.; Springer: Berlin/Heidelberg, Germany, 2007.

41. Damartzis, T.; Zabaniotou, A. Thermochemical conversion of biomass to second generation biofuels through integrated process design-A review. Renew. Sustain. Energy Rev. 2011, 15, 366-378. [CrossRef]

42. Bulushev, D.; Ross, J. Catalysis for conversion of biomass to fuels via pyrolysis and gasification: A review. Catal. Today 2011, 171, 1-13. [CrossRef]

43. Bridgwater, A.V.; Double, J.M. Production costs of liquid fuels from biomass. Fuel 1991, 70, 1209-1224. [CrossRef]

44. Demirbas, A. Biorefinery technologies for biomass upgrading. Energy Sources Part A Recover. Util. Environ. Eff. 2010, 32, 1547-1558. [CrossRef]

45. Centi, G.; Lanzafame, P.; Perathoner, S. Analysis of the alternative routes in the catalytic transformation of lignocellulosic materials. Catal. Today 2011, 167, 14-30. [CrossRef]

46. Cherubini, F.; Strømman, A.H. Principles of biorefining. In Biofuels: Alternative Feedstocks and Conversion Processes; Pandey, A., Larroche, C., Ricke, S.C., Dussap, C.-G., Gnansounou, E., Dussap, C.-G., Eds.; Academic Press: Cambridge, MA, USA, 2011.

47. Kokossis, A.C.; Yang, A. On the use of systems technologies and a systematic approach for the synthesis and the design of future biorefineries. Comput. Chem. Eng. 2010, 34, 1397-1405. [CrossRef]

48. Tsai, W.; Lin, C.; Yeh, C. An analysis of biodiesel fuel from waste edible oil in Taiwan. Renew. Sustain. Energy Rev. 2007, 11, 838-857. [CrossRef]

49. Lebo, S.E., Jr.; Gargulak, J.D.; McNally, T.J. Lignin. In Kirk-Othmer Encyclopedia of Chemical Technology; Wiley Online Library: Hoboken, NJ, USA, 2000.

50. Wardrop, A.B. The structure of the cell wall in lignifield collenchyma of Eryngium sp.(Umbelliferae). Aust. J. Bot. 1969, 17, 229-240. [CrossRef]

51. Glazer, A.N.; Nikaido, H. Microbial Biotechnology: Fundamentals of Applied Microbiology; Cambridge University Press: Cambridge, UK, 2007.

52. Koutinas, A.A.; Wang, R.; Campbell, G.M.; Webb, C. A Whole Crop Biorefinery System: A Closed System for the Manufacture of Non-food Products from Cereals. In Biorefineries-Industrial Processes and Products; Wiley-VCH Verlag GmbH: Weinheim, Germany, 16 December 2005.

53. Deswarte, F.E.I.; Clark, J.H.; Wilson, A.J.; Hardy, J.J.E.; Marriott, R.; Chahal, S.P.; Jackson, C.; Heslop, G.; Birkett, M.; Bruce, T.J.; et al. Toward an integrated straw-based biorefinery. Biofuels Bioprod. Biorefining 2007, 1, 245-254. [CrossRef]

54. Wenzl, H. The Chemical Technology of Wood; Elsevier: Amsterdam, The Netherlands, 2012.

55. Mosier, N.; Wyman, C.; Dale, B.; Elander, R.; Lee, Y.; Holtzapple, M.; Ladisch, M. Features of promising technologies for pretreatment of lignocellulosic biomass. Bioresour. Technol. 2005, 96, 673-686. [CrossRef]

56. Mussatto, S.I.; Teixeira, J.A. Lignocellulose as raw material in fermentation processes. In Current Research, Technology and Education Topics in Applied Microbiology and Microbial Biotechnology; Formatex Research Center: Badajoz, Spain, 2010. 
57. Pan, X.; Gilkes, N.; Kadla, J.; Pye, K.; Saka, S.; Gregg, D.; Ehara, K.; Xie, D.; Lam, D.; Saddler, J. Bioconversion of Hybrid Poplar to Ethanol and Co-Products Using an Organosolv Fractionation Process: Optimization of Process Yields. Biotechnol. Bioeng. 2006, 94, 851-861. [CrossRef]

58. Achten, W.M.; Mathijs, E.; Verchot, L.; Singh, V.P.; Aerts, R.; Muys, B. Jatropha biodiesel fueling sustainability? Biofuels Bioprod. Biorefining 2007, 1, 283-291. [CrossRef]

59. Cybulska, I.; Chaturvedi, T.; Brudecki, G.P.; Kádár, Z.; Meyer, A.S.; Baldwin, R.M.; Thomsen, M.H. Bioresource Technology Chemical characterization and hydrothermal pretreatment of Salicornia bigelovii straw for enhanced enzymatic hydrolysis and bioethanol potential. Bioresour. Technol. 2014, 153, 165-172. [CrossRef]

60. Nwobi, A. Techno-economic Evaluation of Biofuel Production from Organic Fraction of Municipal Solid Waste (OFMSW). Master's Thesis, Masdar Institute of Science and Technology, Abu Dhabi, UAE, 2013.

61. Mulder, W. Proteins in Biomass Streams; Food \& Biobased Research: Wageningen, The Netherlands, 2010.

62. Soh, L.; Montazeri, M.; Haznedaroglu, B.Z.; Kelly, C.; Peccia, J.; Eckelman, M.J.; Zimmerman, J.B. Evaluating microalgal integrated biorefinery schemes: Empirical controlled growth studies and life cycle assessment. Bioresour. Technol. 2014, 151, 19-27. [CrossRef]

63. Vanthoor-Koopmans, M.; Wijffels, R.H.; Barbosa, M.J.; Eppink, M.H.M. Biorefinery of microalgae for food and fuel. Bioresour. Technol. 2013, 135, 142-149. [CrossRef]

64. Kachrimanidou, V.; Kopsahelis, N.; Alexandri, M.; Strati, A.; Gardeli, C.; Papanikolaou, S.; Komaitis, M.; Kookos, I.K.; Koutinas, A.A. Integrated sunflower-based biorefinery for the production of antioxidants, protein isolate and poly (3-hydroxybutyrate). Ind. Crops Prod. 2015, 71, 106-113. [CrossRef]

65. Anastopoulos, G.; Zannikou, Y.; Stournas, S.; Kalligeros, S. Transesterification of Vegetable Oils with Ethanol and Characterization of the Key Fuel Properties of Ethyl Esters. Energies 2009, 2, 362-376. [CrossRef]

66. Du, Z.; Mohr, M.; Ma, X.; Cheng, Y.; Lin, X.; Liu, Y.; Zhou, W.; Chen, P.; Ruan, R. Hydrothermal pretreatment of microalgae for production of pyrolytic bio-oil with a low nitrogen content. Bioresour. Technol. 2012, 120, 13-18. [CrossRef]

67. Helle, S.; Bennett, N.; Lau, K.; Matsui, J.; Duff, S. A kinetic model for production of glucose by hydrolysis of levoglucosan and cellobiosan from pyrolysis oil. Carbohydr. Res. 2007, 342, 2365-2370. [CrossRef]

68. Ruiz, H.A.; Conrad, M.; Sun, S.N.; Sanchez, A.; Rocha, G.J.M.; Romaní, A.; Castro, E.; Torres, A.; Rodríguez-Jasso, R.M.; Andrade, L.P.; et al. Engineering aspects of hydrothermal pretreatment: From batch to continuous operation, scale-up and pilot reactor under biorefinery concept. Bioresour. Technol. 2020, 299, 122685. [CrossRef]

69. Taherzadeh, M.M.J.; Karimi, K. Pretreatment of lignocellulosic wastes to improve ethanol and biogas production: A review. Int. J. Mol. Sci. 2008, 9, 1621-1651. [CrossRef]

70. Hosseini, S.; Shah, N. Multiscale modelling of hydrothermal biomass pretreatment for chip size optimization. Bioresour. Technol. 2009, 100, 2621-2628. [CrossRef]

71. Heitz, M.; Vincent, D.; Chornet, E.; Overend, R.P.; Sastre, H. Solvent Effects on Liquefaction: Solubilization Profiles of a Tropical Prototype Wood, Eucalyptus, in the Presence of Simple Alcohols, Ethylene Glycol, Water and Phenols. In Research in Thermochemical Biomass Conversion; Springer: Berlin/Heidelberg, Germany, 1988.

72. Larsson, S.; Palmqvist, E.; Hahn-Hägerdal, B.; Tengborg, C.; Stenberg, K.; Zacchi, G.; Nilvebrant, N.O. The generation of fermentation inhibitors during dilute acid hydrolysis of softwood. Enzym. Microb. Technol. 1999, 24, 151-159. [CrossRef]

73. Thomsen, M.H.; Thygesen, A.; Thomsen, A.B. Identification and characterization of fermentation inhibitors formed during hydrothermal treatment and following SSF of wheat straw. Appl. Microbiol. Biotechnol. 2009, 83, 447-455. [CrossRef]

74. Garrote, G.; Dominguez, H.; Parajo, J. Hydrothermal processing of lignocellulosic materials. Holz als Roh und Werkst. 1999, 57, 191-202. [CrossRef]

75. Argyros, D.A.; Tripathi, S.A.; Barrett, T.F.; Rogers, S.R.; Feinberg, L.F.; Olson, D.G.; Foden, J.M.; Miller, B.B.; Lynd, L.R.; Hogsett, D.A.; et al. High ethanol titers from cellulose by using metabolically engineered thermophilic, anaerobic microbes. Appl. Environ. Microbiol. 2011, 77, 8288-8294. [CrossRef]

76. Montgomery, L.F.R.; Bochmann, G. Pretreatment of Feedstock for Enhanced Biogas Production; IEA Bioenergy: Cork, Ireland, 2015.

77. Chen, C.-Y.; Yeh, K.-L.; Aisyah, R.; Lee, D.-J.; Chang, J.-S. Cultivation, photobioreactor design and harvesting of microalgae for biodiesel production: A critical review. Bioresour. Technol. 2011, 102, 71-81. [CrossRef] 
78. Fitzgerald, G.C.; Themelis, N.J. Technical and Economic Analysis of Pre-Shredding Municipal Solid Wastes Prior to Disposal. Master's Thesis, Columbia University, New York, NY, USA, 2009.

79. Conde-Mejia, C.; Jimenez-Gutierrez, A. A comparison of pretreatment methods for bioethanol production from lignocellulosic materials. Process Saf. Environ. Prot. 2012, 90, 189-202. [CrossRef]

80. Butler, N. How Petrochemicals are Fuelling Oil Demand. Available online: https://www.ft.com/content/ 5ae88252-cb9b-11e8-b276-b9069bde0956 (accessed on 20 March 2020).

81. IEA. The Future of Petrochemicals; IEA: Paris, France, 2018.

82. Team, C.W.; Pachauri, R.K.; Meyer, L.A. Climate Change 2014: Synthesis Report. Contribution of Working Groups I, II and III to the Fifth Assessment Report of the Intergovernmental Panel on Climate Change; IPCC: Geneva, Switzerland, 2014.

83. Kromus, S.; Wachter, B.; Koschuh, W.; Mandl, M.; Krotscheck, C.; Narodoslawsky, M. The green biorefinery Austria-development of an integrated system for green biomass utilization. Chem. Biochem. Eng. Q. 2004, 18, 7-12.

84. Bozell, J.J.; Petersen, G.R. Technology development for the production of biobased products from biorefinery carbohydrates-the US Department of Energy's “Top 10" revisited. Green Chem. 2010, 12, 539. [CrossRef]

85. Naik, S.N.N.; Goud, V.V.; Rout, P.K.; Dalai, A.K. Production of first and second generation biofuels: A comprehensive review. Renew. Sustain. Energy Rev. 2010, 14, 578-597. [CrossRef]

86. Van Ree, R.; Annevelink, B. Status Report Biorefinery 2007; Food \& Biobased Research: Wageningen, The Netherlands, 2007.

87. Kamm, B.; Gruber, P.; Kamm, M. Biorefineries-Industrial Processes and Products, 1st ed.; Wiley-VCH: Weinheim, Germany, 2007.

88. Chandel, A.K.; Chandrasekhar, G.; Silva, M.B.; Silvério da Silva, S. The realm of cellulases in biorefinery development. Crit. Rev. Biotechnol. 2012, 32, 187-202. [CrossRef]

89. Psycha, M.; Pyrgakis, K.; Kokossis, A.C. Integrated Designs of Microalgae Biorefineries Using a Fixed Selection of Halophytic Algae. Energy 2014, 50, 275-301.

90. Gebreslassie, B.; Waymire, R.; You, F. Sustainable design and synthesis of algae based biorefinery for simultaneous hydrocarbon biofuel production and carbon sequestration. AIChE J. 2013, 59, 1599-1621. [CrossRef]

91. Brennan, L.; Owende, P. Biofuels from microalgae-a review of technologies for production, processing, and extractions of biofuels and co-products. Renew. Sustain. Energy Rev. 2010, 14, 557-577. [CrossRef]

92. Dale, B. 'Greening'the chemical industry: Research and development priorities for biobased industrial products. J. Chem. Technol. Biotechnol. 2003, 70, 1093-1103. [CrossRef]

93. Sues, A.; Juraščík, M.; Ptasinski, K. Exergetic evaluation of 5 biowastes-to-biofuels routes via gasification. Energy 2010, 35, 996-1007. [CrossRef]

94. O'Keeffe, S.; Schulte, R.P.O.; Sanders, J.P.M.; Struik, P.C. II. Economic assessment for first generation green biorefinery (GBR): Scenarios for an Irish GBR blueprint. Biomass Bioenergy 2012, 41, 1-13.

95. Santamaría-Fernández, M.; Molinuevo-Salces, B.; Lübeck, M.; Uellendahl, H. Biogas potential of green biomass after protein extraction in an organic biorefinery concept for feed, fuel and fertilizer production. Renew. Energy 2017, 129, 769-775. [CrossRef]

96. Thomsen, M.H.; Bech, D.; Kiel, P. Manufacturing of stabilised Brown juice for L-lysine production from university lab scale over pilot scale to industrial production. Chem. Biochem. Eng. Q. 2004, 18, 37-46.

97. Arora, A.; Banerjee, J.; Vijayaraghavan, R.; Macfarlane, D.; Patti, A.F. Industrial Crops \& Products Process design and techno-economic analysis of an integrated mango processing waste biore fi nery. Ind. Crop. Prod. 2018, 116, 24-34.

98. Rajendran, K.; Kankanala, H.R.; Martinsson, R.; Taherzadeh, M.J. Uncertainty over techno-economic potentials of biogas from municipal solid waste (MSW): A case study on an industrial process. Appl. Energy 2014, 125, 84-92. [CrossRef]

99. Niziolek, A.M.; Onel, O.; Floudas, C.A. Municipal solid waste to liquid transportation fuels, olefins, and aromatics: Process synthesis and deterministic global optimization. Comput. Chem. Eng. 2017, 102, 169-187. [CrossRef]

100. Montagnana, M.; Leme, V.; Henrique, M.; Eduardo, E.; Lora, S.; José, O.; Marciano, B. Resources, Conservation and Recycling Techno-economic analysis and environmental impact assessment of energy recovery from Municipal Solid Waste ( MSW ) in Brazil. Resour. Conserv. Recycl. 2014, 87, 8-20. 
101. Han, W.; Fang, J.; Liu, Z.; Tang, J. Techno-economic evaluation of a combined bioprocess for fermentative hydrogen production from food waste. Bioresour. Technol. 2015, 202, 107-112. [CrossRef]

102. Demichelis, F.; Fiore, S.; Pleissner, D.; Venus, J. Technical and economic assessment of food waste valorization through a biore fi nery chain. Renew. Sustain. Energy Rev. 2018, 94, 38-48. [CrossRef]

103. Shahzad, K.; Narodoslawsky, M.; Sagir, M.; Ali, N.; Ali, S.; Rashid, M.I.; Ismail, I.M.I.; Koller, M. Techno-economic feasibility of waste biorefinery: Using slaughtering waste streams as starting material for biopolyester production. Waste Manag. 2017, 67, 73-85. [CrossRef]

104. Zhang, Y.; Dubé, M.A.; McLean, D.D.; Kates, M. Biodiesel production from waste cooking oil: 1 . Process design and technological assessment. Bioresour. Technol. 2003, 89, 1-16. [CrossRef]

105. Zhang, Y.; Dubé, M.A.; McLean, D.D.; Kates, M. Biodiesel production from waste cooking oil: 2. Economic assessment and sensitivity analysis. Bioresour. Technol. 2003, 90, 229-240. [CrossRef]

106. Audsley, E.; Sells, J.E. Determining the Profitability of a Wholecrop Biorefinery. In Cereals; Springer: Berlin/Heidelberg, Germany, 1997.

107. Wooley, R.; Ruth, M.; Sheehan, J.; Ibsen, K.; Majdeski, H.; Galvez, A. Lignocellulosic Biomass to Ethanol Process Design and Economics Utilizing Co-Current Dilute Acid Prehydrolysis and Enzymatic Hydrolysis Current and Futuristic Scenarios; National Renewable Energy Lab.: Golden, CO, USA, 1999.

108. Ezeji, T.C.; Qureshi, N.; Blaschek, H.P. Production of acetone butanol (AB) from liquefied corn starch, a commercial substrate, using Clostridium beijerinckii coupled with product recovery by gas stripping. J. Ind. Microbiol. Biotechnol. 2007, 34, 771-777. [CrossRef]

109. Qureshi, N.; Saha, B.C.; Cotta, M.A.; Singh, V. An economic evaluation of biological conversion of wheat straw to butanol: A biofuel. Energy Convers. Manag. 2013, 65, 456-462. [CrossRef]

110. Kaparaju, P.; Serrano, M.; Thomsen, A.B.; Kongjan, P.; Angelidaki, I. Bioethanol, biohydrogen and biogas production from wheat straw in a biorefinery concept. Bioresour. Technol. 2009, 100, 2562-2568. [CrossRef] [PubMed]

111. Baroia, G.N.; Gavalab, H.N.; Westermanna, P.; Skiadas, I.V. Fermentative production of butyric acid from wheat straw: Economic evaluation. Ind. Crop. Prod. 2017, 104, 68-80. [CrossRef]

112. Yuan, Z.; Wen, Y.; Kapu, N.S.; Beatson, R. Evaluation of an organosolv-based biorefinery process to fractionate wheat straw into ethanol and co-products. Ind. Crops Prod. 2018, 121, 294-302. [CrossRef]

113. Cherubini, F.; Jungmeier, G. LCA of a biorefinery concept producing bioethanol, bioenergy, and chemicals from switchgrass. Int. J. Life Cycle Assess. 2010, 15, 53-66. [CrossRef]

114. Villegas, J.D.; Gnansounou, E. Techno-economic and environmental evaluation of lignocellulosic biochemical refineries: Need for a modular platform for integrated assessment (MPIA). J. Sci. Ind. Res. 2008, 67, 927-940.

115. Mariano, A.P.; Dias, M.O.S.; Junqueira, T.L.; Cunha, M.P.; Bonomi, A.; Filho, R.M. Butanol production in a first-generation Brazilian sugarcane biorefinery: Technical aspects and economics of greenfield projects. Bioresour. Technol. 2013, 135, 316-323. [CrossRef]

116. Buruiana, C.T.; Vizireanu, C.; Garrote, G.; Parajó, J.C. Optimization of corn stover biorefinery for coproduction of oligomers and second generation bioethanol using non-isothermal autohydrolysis. Ind. Crops Prod. 2014, 54, 32-39. [CrossRef]

117. Luo, L.; Voet EVan, D.e.r.; Huppes, G.; van der Voet, E.; Huppes, G. Biorefining of lignocellulosic feedstock-Technical, economic and environmental considerations. Bioresour. Technol. 2010, 101, 5023-5032. [CrossRef]

118. Kazi, F.K.; Fortman, J.; Anex, R.; Kothandaraman, G.; Hsu, D.; Aden, A.; Dutta, A. Techno-Economic Analysis of Biochemical Scenarios for Production of Cellulosic Ethanol; National Renewable Energy Lab.: Golden, CO, USA, 2010.

119. Giarola, S.; Romain, C.; Williams, C.K.; Hallett, J.P.; Shah, N. Techno-economic assessment of the production of phthalic anhydride from corn stover. Chem. Eng. Res. Des. 2015, 7, 181-194. [CrossRef]

120. Meyer, P.A.; Tews, I.J.; Magnuson, J.K.; Karagiosis, S.A.; Jones, S.B. Techno-economic analysis of corn stover fungal fermentation to ethanol. Appl. Energy 2013, 111, 657-668. [CrossRef]

121. Wright, M.M.; Daugaard, D.E.; Satrio, J.A.; Brown, R.C.; Daugaard, D.E.; Hsu, D.D. Techno-economic analysis of biomass fast pyrolysis to transportation fuels. Fuel 2013, 89, 463-469.

122. Chen, S.; Xu, Z.; Li, X.; Yu, J.; Cai, M.; Jin, M. Integrated bioethanol production from mixtures of corn and corn stover. Bioresour. Technol. 2018, 258, 18-25. [CrossRef] 
123. Tyner, W.E. The US ethanol and biofuels boom: Its origins, current status, and future prospects. Bioscience 2008, 58, 646-653. [CrossRef]

124. Ekman, A.; Campos, M.; Lindahl, S.; Co, M.; Borjesson, P.; Karlson, N.E.; Turner, C. Bioresource utilisation by sustainable technologies in new value-added biorefinery concepts - two case studies from food and forest industry. J. Clean. 2013, 57, 46-58. [CrossRef]

125. Sarkar, S.; Kumar, A.; Sultana, A. Biofuels and biochemicals production from forest biomass in Western Canada. Energy 2011, 36, 6251-6262. [CrossRef]

126. Sarkar, S.; Kumar, A. Large-scale biohydrogen production from bio-oil. Bioresour. Technol. 2010, 101,7350-7361. [CrossRef]

127. Shabangu, S.; Woolf, D.; Fisher, E.M.; Angenent, L.T.; Lehmann, J. Techno-economic assessment of biomass slow pyrolysis into different biochar and methanol concepts. Fuel 2014, 117, 742-748. [CrossRef]

128. Trippe, F.; Fröhling, M.; Schultmann, F.; Stahl, R.; Henrich, E.; Dalai, A. Comprehensive techno-economic assessment of dimethyl ether (DME) synthesis and Fischer-Tropsch synthesis as alternative process steps within biomass-to-liquid production. Fuel Process. Technol. 2013, 106, 577-586. [CrossRef]

129. Tan, E.C.D.; Talmadge, M.; Dutta, A.; Hensley, J.; Schaidle, J.; Biddy, M.; Humbird, D.; Snowden-Swan, L.J.; Ross, J.; Sexton, D.; et al. Process Design and Economics for the Conversion of Lignocellulosic Biomass to Hydrocarbons via Indirect Liquefaction. Thermochemical Research Pathway to High-Octane Gasoline Blendstock Through Methanol/Dimethyl Ether Intermediates; National Renewable Energy Lab.: Golden, CO, USA, 2015.

130. Dutta, A.; Sahir, A.; Tan, E.; Humbird, D.; Snowden-swan, L.J.; Meyer, P.; Ross, J.; Sexton, D.; Yap, R.; Lukas, J.; et al. Process Design and Economics for the Conversion of Lignocellulosic Biomass to Hydrocarbon Fuels Thermochemical Research Pathways with In Situ and Ex Situ Upgrading of Fast Pyrolysis Vapors; National Renewable Energy Lab.: Golden, CO, USA; Pacific NorthwestNational Lab: Richland, NJ, USA, 2015.

131. Haro, P.; Trippe, F.; Stahl, R.; Henrich, E. Bio-syngas to gasoline and olefins via DME-A comprehensive techno-economic assessment. Appl. Energy 2013, 108, 54-65. [CrossRef]

132. Jones, S.; Meyer, P.; Snowden-Swan, L.; Asanga, P.; Eric, T.; Abhijit, D.; Jacob, J.; Cafferty, K. Process Design and Economics for the Conversion of Lignocellulosic Biomass to Hydrocarbon Fuels Fast Pyrolysis and Hydrotreating Bio-Oil Pathway; National Renewable Energy Lab.: Golden, CO, USA; Pacific Northwest National Lab.: Richland, NJ, USA; Idaho National Lab.: Idaho Falls, ID, USA, 2013.

133. Sanchez, A.; Valdez-Vazquez, I.; Soto, A.; Sanchez, S.; Tavarez, D. Biomass and Bioenergy Lignocellulosic n-butanol co-production in an advanced biore fi nery using mixed cultures. Biomass Bioenergy 2017, 102, 1-12. [CrossRef]

134. Jang, M.O.; Choi, G. Techno-economic analysis of butanol production from lignocellulosic biomass by concentrated acid pretreatment and hydrolysis plus continuous fermentation. Biochem. Eng. J. 2018, 134, 30-43. [CrossRef]

135. Wang, W. Techno-economic analysis of a bio-refinery process for producing Hydro-processed Renewable Jet fuel from Jatropha. Renew. Energy 2016, 95, 63-73. [CrossRef]

136. Zaafouri, K.; Ziadi, M.; Ben Farah, R.; Farid, M.; Hamdi, M.; Regaya, I. Potential of Tunisian Alfa (Stipa tenassicima) fibers for energy recovery to $2 \mathrm{G}$ bioethanol: Study of pretreatment, enzymatic saccharification and fermentation. Biomass Bioenergy 2016, 94, 66-77. [CrossRef]

137. Tirpanalan, Ö.; Reisinger, M.; Smerilli, M.; Huber, F.; Neureiter, M.; Kneifel, W.; Novalin, S. Wheat bran biorefinery-An insight into the process chain for the production of lactic acid. Bioresour. Technol. 2015, 180, 242-249. [CrossRef]

138. Ahmad, M.; Mohd, K.; Arif, H.; Noriznan, M.; Salihon, J.; Shirai, Y.; Ali, M. Case study for a palm biomass biore fi nery utilizing renewable non-food sugars from oil palm frond for the production of poly (3-hydroxybutyrate).Bioplastic. J. Clean. Prod. 2015, 87, 284-290.

139. He, M.X.; Wang, J.L.; Qin, H.; Shui, Z.X.; Zhu, Q.L.; Wu, B.; Tan, F.R.; Pan, K.; Hu, Q.C.; Dai, L.C.; et al. Bamboo: A new source of carbohydrate for biorefinery. Carbohydr. Polym. 2014, 111, 645-654. [CrossRef]

140. Dassanayake, G.D.M.; Kumar, A. Techno-economic assessment of triticale straw for power generation. Appl. Energy 2012, 98, 236-245. [CrossRef]

141. Zhu, L. Biorefinery as a promising approach to promote microalgae industry: An innovative framework. Renew. Sustain. Energy Rev. 2015, 41, 1376-1384. [CrossRef] 
142. Davis, R.; Kinchin, C.; Markham, J.; Tan, E.; Laurens, L.; Sexton, D.; Knorr, D.; Schoen, P.; Lukas, J. Process Design and Economics for the Conversion of Algal Biomass to Biofuels: Algal Biomass Fractionation to Lipid-and Carbohydrate-Derived Fuel Products; National Renewable Energy Lab.: Golden, CO, USA, 2014.

143. Jung, K.A.; Lim, S.R.; Kim, Y.; Park, J.M. Potentials of macroalgae as feedstocks for biorefinery. Bioresour. Technol. 2013, 135, 182-190. [CrossRef]

144. Cheng, J.; Zhang, M.; Song, W.; Xia, A.; Zhou, J.; Cen, K. Cogeneration of hydrogen and methane from Arthrospira maxima biomass with bacteria domestication and enzymatic hydrolysis. Int. J. Hydrogen Energy 2011, 36, 1474-1481. [CrossRef]

145. Yang, Z.; Guo, R.; Xu, X.; Fan, X.; Luo, S. Hydrogen and methane production from lipid-extracted microalgal biomass residues. Int. J. Hydrogen Energy 2011, 36, 3465-3470. [CrossRef]

146. Xia, A.; Cheng, J.; Lin, R.; Lu, H.; Zhou, J.; Cen, K. Comparison in dark hydrogen fermentation followed by photo hydrogen fermentation and methanogenesis between protein and carbohydrate compositions in Nannochloropsis oceanica biomass. Bioresour. Technol. 2013, 138, 204-213. [CrossRef] [PubMed]

147. Chew, T.; Bhatia, S. Catalytic processes towards the production of biofuels in a palm oil and oil palm biomass-based biorefinery. Bioresour. Technol. 2008, 99, 7911-7922. [CrossRef] [PubMed]

148. Laser, M.; Jin, H.; Jayawardhana, K.; Dale, B.E.; Lynd, L.R. Projected mature technology scenarios for conversion of cellulosic biomass to ethanol with coproduction thermochemical fuels, power, and/or animal feed protein. Biofuels Bioprod. Biorefining 2009, 3, 231-246. [CrossRef]

149. Pinatti, D.G.; Conte, R.A.; Soares, A.G.; Pereira, M.L.G.; Romao, E.L.; Ferreira, J.C.; Oliveira, I.; Marton, L.F.M. Biomass refinery as a renewable complement to the petroleum refinery. Int. J. Chem. React. Eng. 2010, 8, A94. [CrossRef]

150. Bao, B.; Ng, D.K.S.; Tay, D.H.S.; Jiménez-Gutiérrez, A.; El-Halwagi, M.M. A shortcut method for the preliminary synthesis of process-technology pathways: An optimization approach and application for the conceptual design of integrated biorefineries. Comput. Chem. Eng. 2011, 35, 1374-1383. [CrossRef]

151. Sharma, P.; Sarker, B.R.; Romagnoli, J.A. A decision support tool for strategic planning of sustainable biorefineries. Comput. Chem. Eng. 2011, 35, 1767-1781. [CrossRef]

(C) 2020 by the authors. Licensee MDPI, Basel, Switzerland. This article is an open access article distributed under the terms and conditions of the Creative Commons Attribution (CC BY) license (http://creativecommons.org/licenses/by/4.0/). 